\title{
Patient satisfaction and self-reported dry eye symptoms in hyperopic patients treated with femtosecond laser in situ keratomileusis
}

This article was published in the following Dove Medical Press journal:

Clinical Ophthalmology

\section{Petri Mäkinen ${ }^{1,2}$ \\ Anne Huhtala ${ }^{1,2}$ \\ Juhani Pietilä ${ }^{1,2}$ \\ Janika Nättinen ${ }^{3}$ \\ Teppo Rajala' \\ Kalle Salmenhaara ${ }^{2}$ \\ Magomed Udratov' \\ Hannu Uusitalo ${ }^{3,4}$}

'Silmäasema Eye Hospital, Tampere, Finland; ${ }^{2}$ Silmäasema Eye Hospital, Helsinki, Finland; ${ }^{3}$ SILK, Department of Ophthalmology, School of Medicine, University of Tampere, Tampere, Finland; ${ }^{4}$ TAUH Eye Centre, Tampere University Hospital, Tampere, Finland

Correspondence: Petri Mäkinen Silmäasema Eye Hospital, Hämeenkatu 6, Tampere FIN-33100, Finland

Tel +358405566783

Email petri_makinen@kolumbus.fi
Purpose: To study self-reported patient satisfaction and dry eye symptoms in hyperopic correction with femtosecond laser-assisted in situ keratomileusis (FS-LASIK).

Patients and methods: Ninety-eight eyes (53 patients) were treated with FS-LASIK for hyperopia. Patients' self-reported dry eye symptoms and satisfaction with near and far vision were graded on the visual analog scale (VAS) preoperatively and 1 month postoperatively.

Results: Ninety-one percent of the eyes with the plano target (54 eyes) achieved an uncorrected distance visual acuity of $20 / 20$ or better. Predictability, defined as spherical equivalent refraction within $\pm 0.5 \mathrm{D}$ of target, was $88 \%$ of all eyes. None of the eyes lost two or more Snellen lines of corrected distance visual acuity. There was no significant change in the self-reported dry eye sensation (VAS score from $2.7 \pm 2.0$ to $2.8 \pm 2.0 ; P=0.66$ ). In 44 monovision patients, satisfaction with both far vision (from $71.2 \pm 19.8$ to $89.2 \pm 8.7 ; P<0.0001$ ) and near vision (from $51.7 \pm 26.2$ to $89.3 \pm 13.2 ; P<0.0001)$ increased significantly. In nine emmetropic patients, satisfaction with neither far vision nor near vision was significantly improved, although there was a clear tendency (from $73.7 \pm 23.7$ to $86.9 \pm 15.3 ; P=0.22$, and from $58.9 \pm 29.1$ to $81.6 \pm 17.4 ; P=0.11$, respectively). In the monovision patient group, far vision satisfaction decreased when dry eye symptoms increased. Monovision patients, as predicted, were more satisfied with their near vision, when postoperative spherical equivalent from target was on the myopic side.

Conclusion: FS-LASIK correction of hyperopia significantly improved patient satisfaction with both near and far vision in monovision patients. Hyperopic patients had no significant changes in postoperative dry eye symptoms compared to preoperative values.

Keywords: femtosecond laser in situ keratomileusis, FS-LASIK, hyperopia, dry eye, patient satisfaction

\section{Plain language summary}

The most widely used refractive surgery to improve vision without spectacles or contact lenses is laser-assisted in situ keratomileusis (LASIK). In femtosecond-LASIK (FS-LASIK), a thin corneal flap is made with a femtosecond laser. The cornea under the lifted flap is then ablated with the excimer laser to reshape the cornea. We studied dry eye symptoms and patient satisfaction of hyperopic (farsighted) eyes treated with FS-LASIK. Hyperopic patients had no significant changes in postoperative dry eye symptoms compared to preoperative values. The risk of increased dry eye symptoms after hyperopic FS-LASIK correction seemed to be as low as in myopic (near sighted) FS-LASIK correction shown in our previous studies. In hyperopic monovision patients, satisfaction with both far and near vision improved significantly. Monovision patients had one eye corrected for far vision and the other eye for near vision. In monovision patients, satisfaction with far vision decreased when dry eye symptoms increased. 


\section{Introduction}

In laser-assisted in situ keratomileusis (LASIK) surgery, LASIK-associated dry eye symptoms have been reported to be the main reason for patient dissatisfaction. ${ }^{1}$ Corneal refractive surgeons also report dry eyes as the most common complication of LASIK. ${ }^{2}$ Transient dry eye symptoms immediately after surgery are reported by up to $95 \%$ of LASIK patients. ${ }^{3}$

Hyperopic correction has been considered challenging, but it has been treated successfully with many techniques. ${ }^{4-9}$ Based on three LASIK studies utilizing microkeratomes for flap creation from 1997 to 1998, the overall satisfaction rate for patients undergoing hyperopic LASIK surgery was $96.3 \%$ and the overall dissatisfaction rate $3.7 \% .{ }^{10}$ In a more recent study also utilizing a microkeratome, the quality of vision was reported as unchanged, better, or significantly better at 12 months as compared to preoperative quality in $96.5 \%$ of spherical hyperopes and $94.4 \%$ of hyperopic astigmatism. Patient satisfaction and dry eye symptoms in hyperopic patients treated with FS-LASIK have rarely been investigated. ${ }^{11-15}$ The present study was undertaken to fill the void in knowledge in how patient satisfaction and dry eye symptoms are affected in patients treated for hyperopia with FS-LASIK. Both emmetropia-targeted patients and monovision patients were included and separately analyzed. In addition to clinical examinations, patient satisfaction with near and far vision and dry eye symptoms were investigated with a self-graded questionnaire. Patients graded their satisfaction and symptoms on the visual analog scale (VAS) before the treatment and 1 month postoperatively.

\section{Patients and methods}

Fifty-three patients ( 31 females and 22 males, 98 eyes) were involved in this retrospective study. Patients were scheduled for FS-LASIK correction for hyperopia at Silmäasema Eye Hospital, either in Tampere or in Helsinki (Finland) between May and December 2016. For the study, we used technical data of the surgery, clinical patient data, and quality control data of patient satisfaction. When a retrospective study with existing patient data is done, the approval of the Ethics Committee is not needed according to the EU legislation. The used data was de-identified.

\section{Preoperative examinations}

All patients had a complete preoperative ophthalmologic examination before the surgery to exclude any pathology that might be a contraindication for the surgery. In addition to biomicroscopy, evaluation of refraction and measurements of uncorrected and corrected distance visual acuity (UDVA and CDVA, respectively), examination included the measurement of intraocular pressure (iCare TA01i; iCare Finland Oy, Vantaa, Finland), corneal thickness, keratometry readings $\left(\mathrm{K}_{1}, \mathrm{~K}_{2}\right.$, and $\mathrm{K}$ axis) and three-dimensional corneal topography (Allegro Oculyzer; Wavelight AG, Erlangen, Germany), and wavefront analysis (Allegro Analyzer; Wavelight AG). The use of soft contact lenses was discontinued a minimum of 1 week before the surgery.

\section{Surgical techniques}

The surgeries were performed by a single experienced surgeon (JP). Prior to the surgery, the following topical eye drop medication was instilled into the eyes: antibiotic levofloxacin $5 \mathrm{mg} / \mathrm{mL}$ (Oftaquix; Santen Oy, Tampere, Finland); diclofenac $1 \mathrm{mg} / \mathrm{mL}$ for pain and inflammation (Voltaren Ophtha; THEA, Clermont-Ferrand, France); brimonidine tartrate $2 \mathrm{mg} / \mathrm{mL}$ to constrict conjunctival vessels (Alphagan; Allergan, Westport, Ireland); and a topical anaesthetic oxybuprocain hydrochloride $4 \mathrm{mg} / \mathrm{mL}$ (Oftan Obucain, Santen Oy). An aspirating speculum (Geuder, no 15,961, Heidelberg, Germany) was used to open the eyelid.

The femtosecond laser used for flap creation was FEMTO LDV Z6 I (Ziemer Ophthalmic Systems, Port, Switzerland) in Tampere (28 patients, 53\% of the patients), and Visumax ${ }^{\circledR}$ (Carl Zeiss Meditec, Jena, Germany) in Helsinki (25 patients, $47 \%$ of the patients). The FEMTO LDV Z6 I delivers $100 \mathrm{~nJ}$ pulse energy and $10 \mathrm{MHz}$ repetition rate. A single-use plastic suction ring with 9.5 -mm diameter was used to create a round flap with a target diameter of $9.3 \mathrm{~mm}$ and hinge length of $4.0 \mathrm{~mm}$. The target flap thickness was 90 or $100 \mu \mathrm{m}$ and the flap edge angle was set from $60^{\circ}$ to $90^{\circ}$. The vacuum pressure was 700 mbar and the cutting time 28 seconds. When the Visumax was used, the target flap thickness was also 90 or $100 \mu \mathrm{m}$ and the flap edge angle was set at $60^{\circ}$. The $\mathrm{M}$ glass suction ring was used with a target flap diameter of $8.9 \mathrm{~mm}$ and target hinge length of $3.8 \mathrm{~mm}$. The cutting time was 18 seconds. The excimer laser treatment was done in both hospitals with Wavelight EX500 (Wavelight AG, Erlangen, Germany).

\section{Post-refractive treatment}

Chloramphenicol- and dexamethasone-containing drops (Oftan Dexa-Chlora, Santen Oyj) with the tapered dose were used for the first 7 days - on the operation day for every 2 hours; on day 2 for five times daily; on days 3 and 4 for 
four times daily; on days 5 and 6 for three times daily; and on day 7 for two times daily. Artificial tear drops were used as needed from day 1. Gel-like moisturizing eye drops were used for the night and every morning. The frequency of using artificial tears was not monitored.

\section{Follow-up examinations}

On the follow-up visit 1 month postoperatively, the same examinations carried out preoperatively excluding wavefront analysis, were performed, and a patient questionnaire was filled in. All complications during the procedures and the 1-month follow-up time were recorded.

\section{Patient questionnaire}

Patients filled a questionnaire before the operation and 1 month postoperatively to rate their subjective dry eye symptoms and satisfaction for far vision and near vision separately. Dry eye symptoms were graded on the VAS from 0 (no dryness) to 10 (extremely dry eyes). The patients also rated their satisfaction for far and near vision separately on the VAS from 0 (poor) to 100 (excellent). The patients marked their subjective response on the linear visual line, and the length of the line segment was measured and recorded for analyses.

For 44 of the 53 patients, a monovision approach was used; the dominant eye was targeted for emmetropia while the non-dominant eye had a myopic target sphere (from -0.25 to $-1.75 \mathrm{D}$ ). Patient selection criteria are shown in Figure 1. Five patients were targeted for emmetropia in both eyes, four patients had only one eye treated and targeted for emmetropia, and four patients had a myopic target sphere (from -1.25 to $-1.75 \mathrm{D}$ ) in one eye.

\section{Statistical methods}

The data were collected and entered into Excel study spreadsheets (Microsoft Corp., Redmond, WA, USA). Values were given as the mean \pm standard deviation. The paired Student's $t$-tests were used for statistical analysis to compare data before and after the treatment. Correlations were used to analyze the relationship between different parameters. The correlations were calculated using the eye with the best postoperative UDVA. For patient satisfaction with near vision, the correlations were calculated using the eye with the myopic target for near vision. We studied the correlations with subjective dry eye symptoms and patient satisfaction with emmetropia and monovision patient data using the following factors: pre- and postoperative spherical equivalent (SEQ) refraction, postoperative SEQ refraction error from the target, postoperative UDVA, postoperative cylinder, postoperative keratometry readings, and patient age. The statistical tests were performed with the GraphPad Prism software (San Diego, CA, USA). A $P$-value $<0.05$

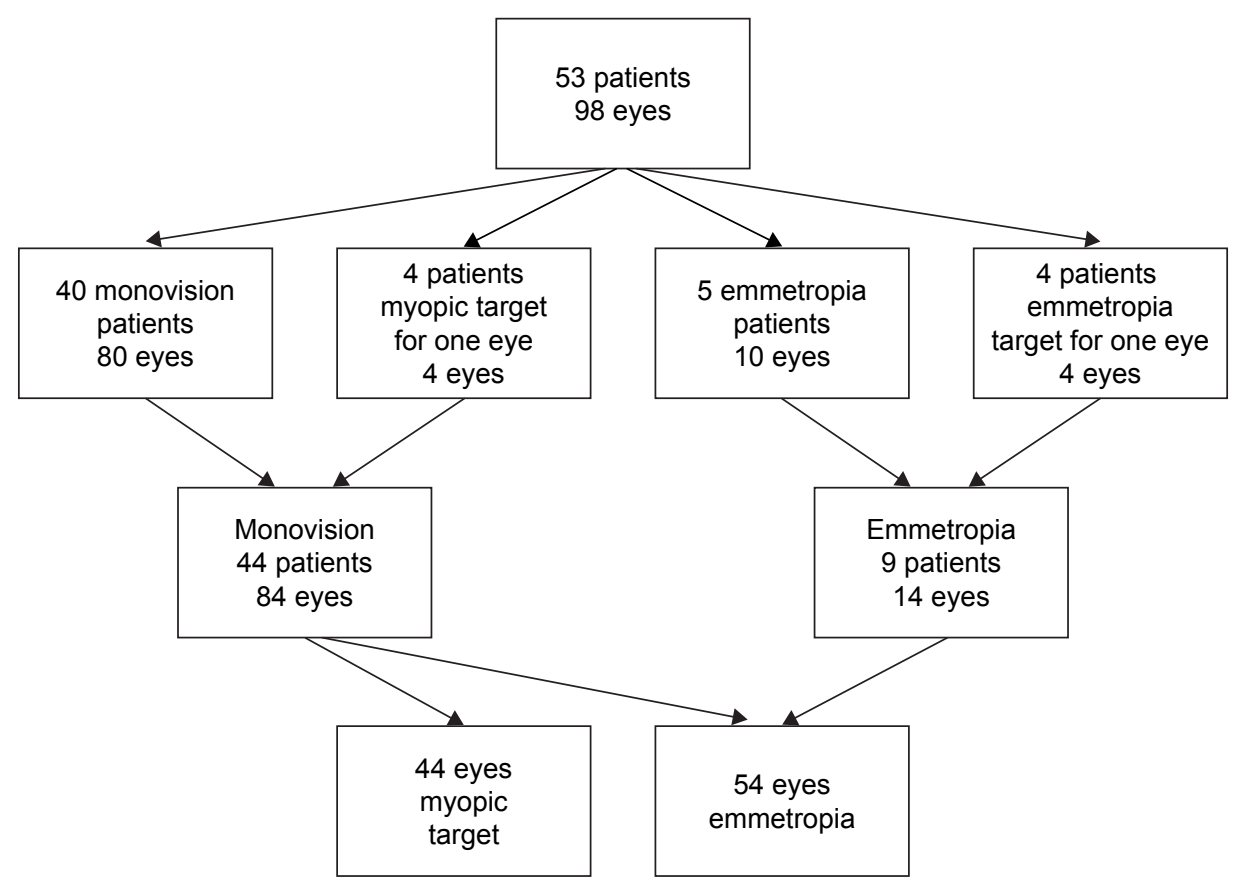

Figure I Flowchart of patient selection. 
was considered statistically significant. Standard graphs and other figures were created using the SigmaPlot software (Systat Software, San Jose, CA, USA).

\section{Results}

Ninety-eight eyes of 53 patients were treated with FS-LASIK for hyperopia. The patients' age range was between 22 and
62 (mean age 49.6 \pm 9.8 years). All patients completed the 1-month follow-up examination.

\section{Refraction}

Preoperative and postoperative patient data are presented in Table 1. The standard graphs for reporting refractive surgery outcomes are presented in Figure 2. The preoperative mean sphere

Table I Preoperative and postoperative patient data

\begin{tabular}{|c|c|c|c|}
\hline Variable & Preoperative & I month & $P$-value \\
\hline Sphere (D) & $\begin{array}{l}+2.24 \pm 1.25 \\
\text { (range: }+0.25 \text { to }+6.25) \\
(\mathrm{N}=98 \text { eyes) } \\
+2.08 \pm 1.10 \\
(\text { range: }+0.025 \text { to }+4.25) \\
(\mathrm{N}=44 \text { monovision eyes) } \\
+2.37 \pm 1.35 \\
(\text { range: }+0.75 \text { to }+6.25) \\
(\mathrm{N}=54 \text { emmetropic eyes) }\end{array}$ & $\begin{array}{l}-0.54 \pm 0.98 \\
\text { (range: }-2.75 \text { to }+1.25) \\
(\mathrm{N}=98 \text { eyes) } \\
-1.53 \pm 0.61 \\
\text { (range: }-2.75 \text { to }+0.25) \\
(\mathrm{N}=44 \text { monovision eyes) } \\
+0.17 \pm 0.37 \\
\text { (range: }-0.50 \text { to }+1.25 \\
(\mathrm{~N}=54 \text { emmetropic eyes) }\end{array}$ & $\begin{array}{l}<0.000 \text { । } \\
<0.000 \text { । } \\
<0.000 \text { । }\end{array}$ \\
\hline Cylinder (D) & $\begin{array}{l}-0.7 \mathrm{I} \pm 0.90 \\
\text { (range: } 0 \text { to } 5.50) \\
(\mathrm{N}=98 \text { eyes) } \\
-0.55 \pm 0.60 \\
\text { (range: } 0 \text { to } 2.00) \\
(\mathrm{N}=44 \text { monovision eyes) } \\
-0.83 \pm 1.08 \\
\text { (range: } 0 \text { to } 5.50) \\
(\mathrm{N}=54 \text { emmetropic eyes) }\end{array}$ & $\begin{array}{l}-0.20 \pm 0.30 \\
\text { (range: } 0 \text { to } \mathrm{I} .25 \text { ) } \\
\text { ( } \mathrm{N}=98 \text { eyes) } \\
-0.22 \pm 0.33 \\
\text { (range: } 0 \text { to } \mathrm{I} .25 \text { ) } \\
(\mathrm{N}=44 \text { monovision eyes) } \\
-0.18 \pm 0.28 \\
\text { (range: } 0 \text { to } \mathrm{I} .00 \text { ) } \\
(\mathrm{N}=54 \text { emmetropic eyes) }\end{array}$ & $\begin{array}{l}<0.000 \text { I } \\
0.0003 \\
<0.000 \text { I }\end{array}$ \\
\hline $\begin{array}{l}\text { Spherical equivalent } \\
\text { Refraction (D) }\end{array}$ & $\begin{array}{l}+1.88 \pm 1.17 \\
(\text { range: }+0.13 \text { to }+5.10) \\
(\mathrm{N}=98 \text { eyes }) \\
+1.80 \pm 1.07 \\
(\text { range: }+0.13 \text { to }+3.88) \\
(\mathrm{N}=44 \text { monovision eyes) } \\
+1.95 \pm 1.26 \\
(\text { range: }+0.25 \text { to }+5.10) \\
(\mathrm{N}=54 \text { emmetropic eyes) }\end{array}$ & $\begin{array}{l}-0.70 \pm 0.96 \\
\text { (range: }-2.75 \text { to }+0.88 \\
\text { ( } \mathrm{N}=98 \text { eyes) } \\
-1.65 \pm 0.54 \\
\text { (range: }-2.75 \text { to }-0.13) \\
(\mathrm{N}=44 \text { monovision eyes) } \\
+0.08 \pm 0.3 \mathrm{I} \\
\text { (range: }-0.50 \text { to }+0.88 \\
(\mathrm{~N}=54 \text { emmetropic eyes) }\end{array}$ & $\begin{array}{l}<0.000 \text { I } \\
<0.000 \text { I } \\
<0.000 \text { I }\end{array}$ \\
\hline Keratometric power $\mathrm{K}_{\mathrm{I}}(\mathrm{D})$ & $\begin{array}{l}42.66 \pm 1.52 \\
\text { (range: } 39.50 \text { to } 47.40) \\
(\mathrm{N}=98 \text { eyes) } \\
42.89 \pm 1.38 \\
\text { (range: } 40.10 \text { to } 47.00) \\
(\mathrm{N}=44 \text { monovision eyes) } \\
42.47 \pm 1.62 \\
\text { (range: } 39.50 \text { to } 47.40) \\
(\mathrm{N}=54 \text { emmetropic eyes) }\end{array}$ & $\begin{array}{l}45.03 \pm 2.12 \\
\text { (range: } 40.70 \text { to } 51.40) \\
(\mathrm{N}=94 \text { eyes) } \\
46.07 \pm 1.90 \\
\text { (range: } 40.70 \text { to } 50.90) \\
(\mathrm{N}=43 \text { monovision eyes) } \\
44.15 \pm 1.91 \\
\text { (range: } 41.40 \text { to } 5 \mathrm{I} .40) \\
(\mathrm{N}=5 \mathrm{I} \text { emmetropic eyes) }\end{array}$ & $\begin{array}{l}<0.000 \text { I } \\
<0.000 \text { I } \\
<0.000 \text { I }\end{array}$ \\
\hline Keratometric power $\mathrm{K}_{2}(\mathrm{D})$ & $\begin{array}{l}43.69 \pm 1.50 \\
\text { (range: } 40.10 \text { to } 48.40) \\
\text { ( } \mathrm{N}=98 \text { eyes) } \\
43.79 \pm 1.43 \\
\text { (range: } 40.40 \text { to } 47.70) \\
(\mathrm{N}=44 \text { monovision eyes) } \\
43.6 \mathrm{I} \pm \mathrm{I} .74 \\
\text { (range: } 40.10 \text { to } 48.40) \\
(\mathrm{N}=54 \text { emmetropic eyes) }\end{array}$ & $\begin{array}{l}46.10 \pm 2.12 \\
\text { (range: } 41.00 \text { to } 54.30) \\
(\mathrm{N}=94 \text { eyes) } \\
47.10 \pm 2.03 \\
\text { (range: } 41.00 \text { to } 51.90) \\
(\mathrm{N}=43 \text { monovision eyes) } \\
45.26 \pm 2.14 \\
\text { (range: } 41.80 \text { to } 54.30) \\
(\mathrm{N}=51 \text { emmetropic eyes) }\end{array}$ & $\begin{array}{l}<0.000 \text { I } \\
<0.000 \text { I } \\
<0.000 \text { I }\end{array}$ \\
\hline
\end{tabular}


was $+2.24 \pm 1.25 \mathrm{D}$ (range +0.25 to $+6.25 \mathrm{D})$ and the mean preoperative cylinder $-0.71 \pm 0.90 \mathrm{D}$ (range 0 to $-5.50 \mathrm{D}$ ) for all eyes studied. The preoperative SEQ refraction was $+1.88 \pm$ $1.17 \mathrm{D}$ (range +0.13 to $+5.10 \mathrm{D}$ ). The preoperative SEQ

A

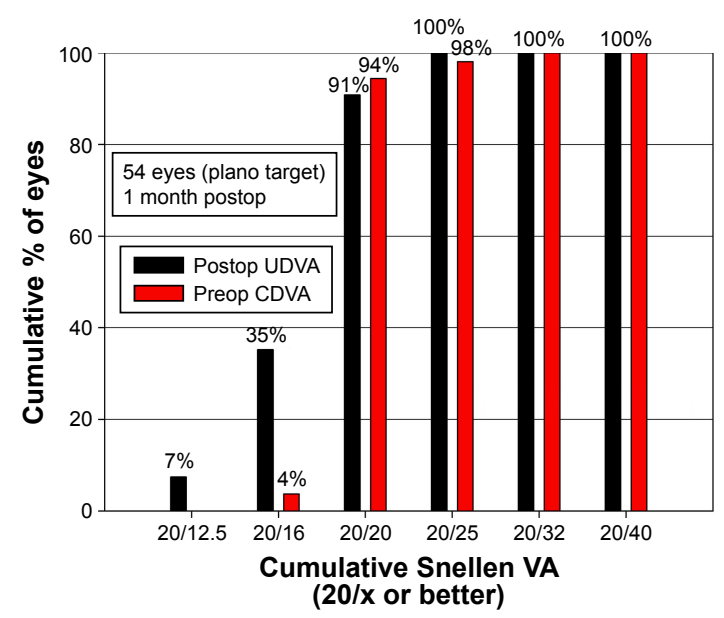

C

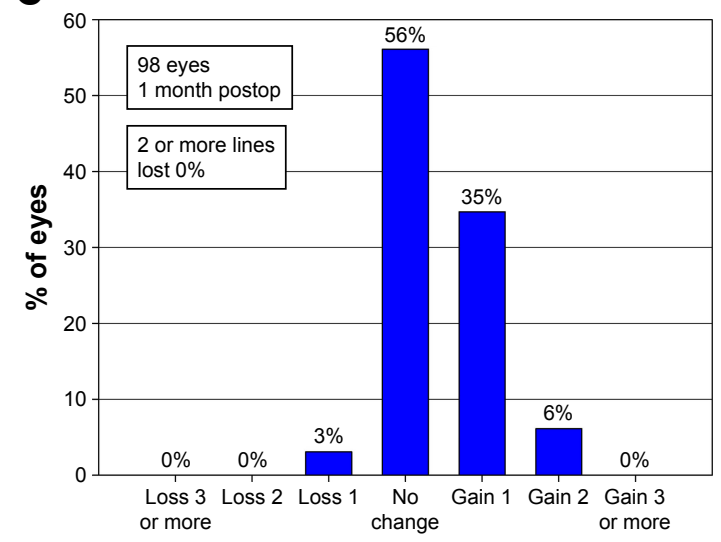

Change in Snellen lines of CDVA

E

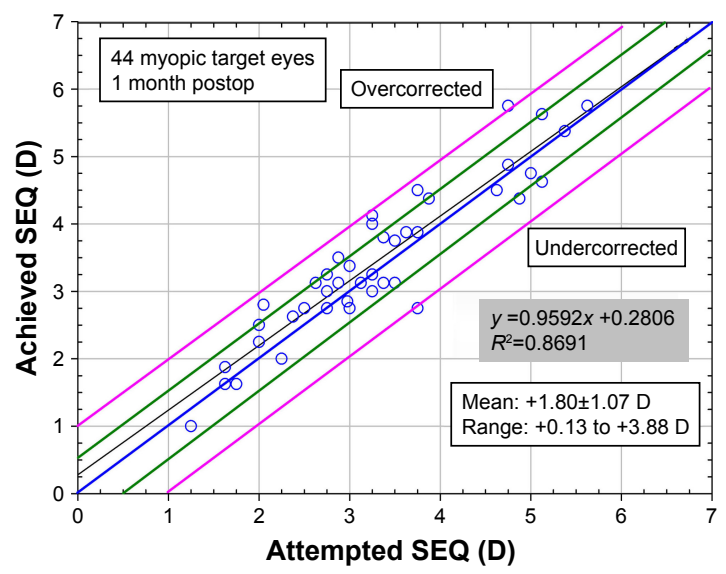

refraction for 54 eyes targeting emmetropia was $+1.95 \pm 1.26 \mathrm{D}$ (range +0.25 to $+5.10 \mathrm{D}$ ) and the postoperative values for this group of eyes were $+0.08 \pm 0.31 \mathrm{D}$ (range -0.50 to $+0.88 \mathrm{D}$ ). The preoperative SEQ refraction for 44 eyes having a myopic

B

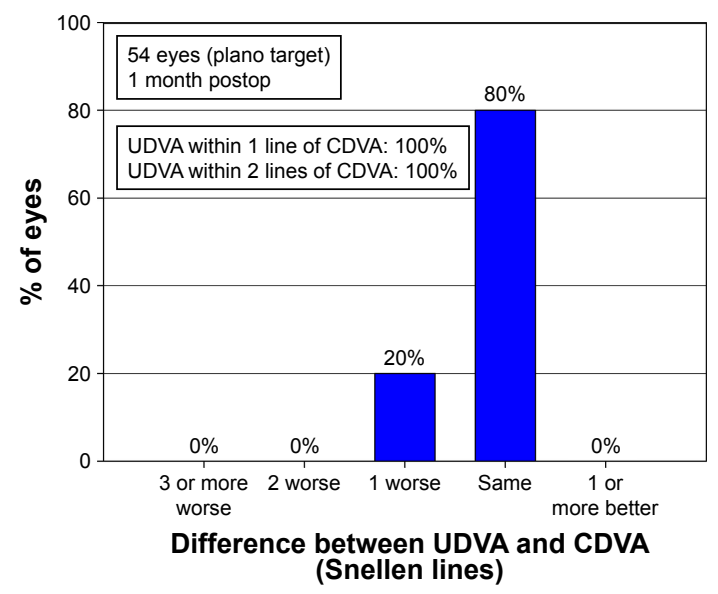

D

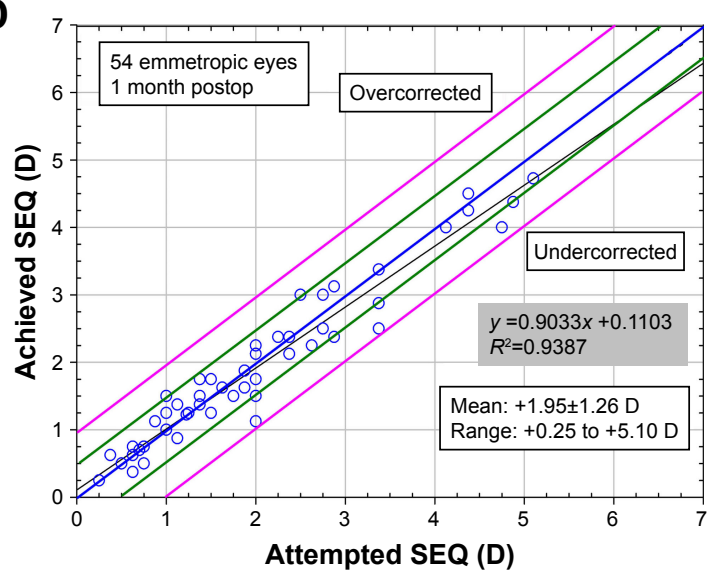

$\mathbf{F}$

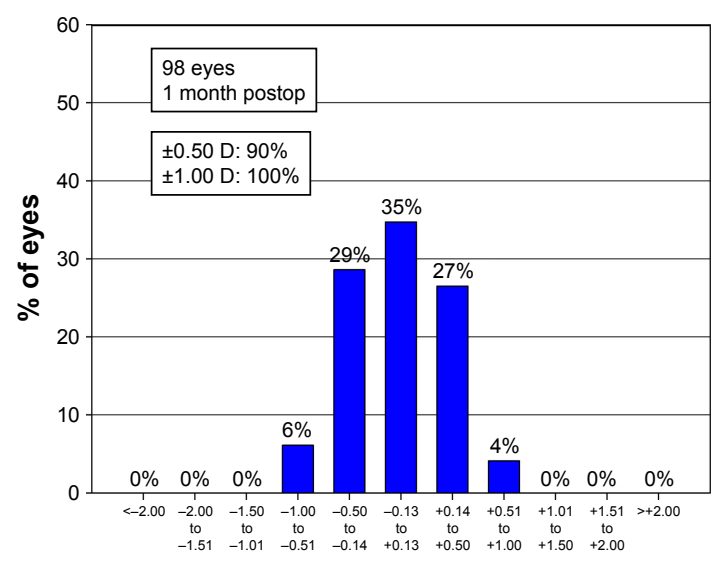

Accuracy of SEQ to intended target (D)

Figure 2 (Continued) 
G

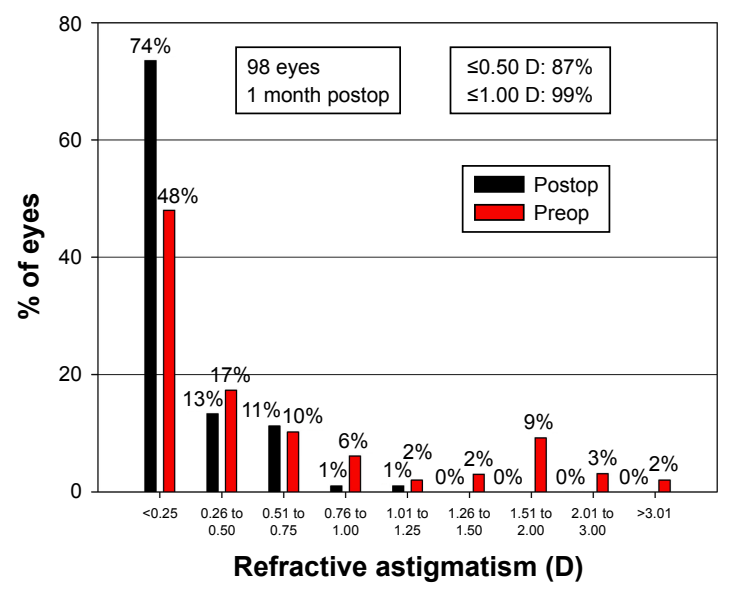

H

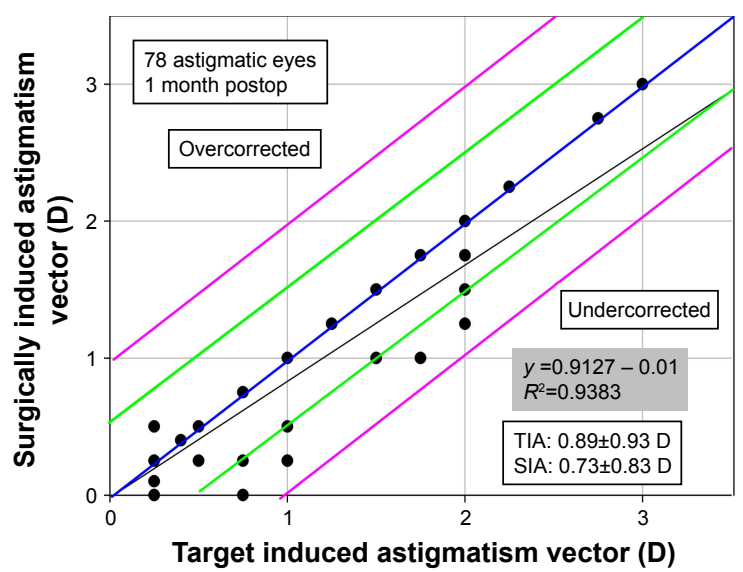

I

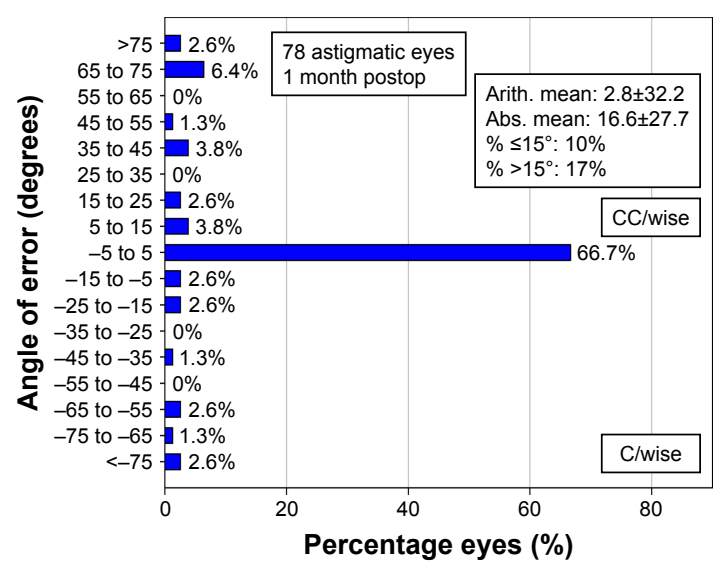

Figure 2 Standard graphs for reporting refractive surgery outcomes. (A) UDVA, (B) UDVA vs CDVA, (C) change in CDVA, (D) SEQ refraction attempted vs achieved in emmetropic eyes, (E) SEQ refraction attempted vs achieved in monovision eyes, (F) SEQ refraction accuracy, (G) refractive astigmatism, (H) TIA vs SIA, (I) refractive astigmatism angle of error. In ( $\mathbf{D}$ and $\mathbf{G})$, the values within $0.5 \mathrm{D}$ are shown by green line and those within I.0 D by pink line.

Abbreviations: Arith, arithmetic; Abs, absolute; CC/wise, counter clockwise; C/wise, clock wise; CDVA, corrected distance visual acuity; preop, preoperative; postop, postoperative; SEQ, spherical equivalent refraction; SIA, surgically induced astigmatism; TIA, target-induced astigmatism; UDVA, uncorrected distance visual acuity.

target was $+1.80 \pm 1.07 \mathrm{D}$ (range +0.13 to $+3.88 \mathrm{D}$ ) and the postoperative values for these eyes were $-1.65 \pm 0.54 \mathrm{D}$ (range -0.13 to $-2.75 \mathrm{D}$ ). The mean postoperative 1-month SE refraction in all eyes was $-0.70 \pm 0.96 \mathrm{D}$ (range -2.75 to $+0.88 \mathrm{D})$ and the 1 -month $\mathrm{SE}$ refraction from the target was $-0.022 \pm 0.374 \mathrm{D}$ (range -1.00 to $+1.00 \mathrm{D}$ ).

\section{Efficacy}

Postoperatively, 91\% of the emmetropic eyes (54 eyes) achieved an UDVA of 20/20 or better.

\section{Predictability}

At 1 month, the refraction was within $\pm 0.50 \mathrm{D}$ of mean target SEQ refraction in $88 \%$ of all eyes. The refraction was within $\pm 1.00 \mathrm{D}$ of mean target SE refraction in $100 \%$ in all eyes.

\section{Safety}

One-month postoperatively, three eyes lost one Snellen line of CDVA. One of these eyes gained the lost line in the follow-up visit and one patient did not have any more follow-ups. One patient needed reoperation due to undercorrection after 2 months.

\section{Patient questionnaire}

Patient data regarding the self-reported dry eye symptoms and patient satisfaction with far and near vision are presented in Table 2. The mean score of the preoperative subjective dry eye sensation was $2.7 \pm 2.0$. The dry eye sensation did not change significantly postoperatively (VAS score 2.8 \pm 2.0 ; $P=0.59)$. Patient satisfaction with both far and near vision was significantly improved after 1 month $(P<0.0001)$. The mean VAS score for patient satisfaction with far vision 
Table 2 Pre- and postoperative dry eye symptoms and patient satisfaction graded by visual analog scaling scores

\begin{tabular}{|c|c|c|c|}
\hline Variable & Preoperative & I month & $P$-value \\
\hline Dry eye symptoms & $\begin{array}{l}2.7 \pm 2.0 \\
\text { (range: } 0.3-7.1) \\
(\mathrm{N}=53 \text { all patients) }\end{array}$ & $\begin{array}{l}2.8 \pm 2.0 \\
\text { (range: } 0-8.0) \\
(\mathrm{N}=53 \text { all patients })\end{array}$ & 0.66 \\
\hline Patient satisfaction, far vision & $\begin{array}{l}71.6 \pm 20.3 \\
\text { (range: } 15-100) \\
(\mathrm{N}=53 \text { patients) } \\
71.2 \pm 19.8 \\
\text { (range: } 28-100) \\
(\mathrm{N}=44 \text { monovision) } \\
73.7 \pm 23.7 \\
\text { (range: } 15-95) \\
\text { ( } \mathrm{N}=9 \text { emmetropia) }\end{array}$ & $\begin{array}{l}88.8 \pm 10.0 \\
\text { (range: } 50-100) \\
(\mathrm{N}=53 \text { patients) } \\
89.2 \pm 8.7 \\
\text { (range: } 60-100) \\
\text { ( } \mathrm{N}=44 \text { monovision) } \\
86.9 \pm 15.3 \\
\text { (range: } 50-100) \\
(\mathrm{N}=9 \text { emmetropia) }\end{array}$ & $\begin{array}{l}<0.000 \text { I } \\
<0.000 \text { I } \\
0.22\end{array}$ \\
\hline Patient satisfaction, near vision & $\begin{array}{l}52.9 \pm 26.6 \\
\text { (range: 5-99) } \\
(\mathrm{N}=53 \text { patients) } \\
51.7 \pm 26.2 \\
\text { (range: } 5-99) \\
(\mathrm{N}=44 \text { monovision) } \\
58.9 \pm 29.1 \\
\text { (range: } 1 \mathrm{I}-86) \\
(\mathrm{N}=9 \text { emmetropia) }\end{array}$ & $\begin{array}{l}88.0 \pm 14.1 \\
\text { (range: } 40-100) \\
(\mathrm{N}=53 \text { patients) } \\
89.3 \pm 13.2 \\
\text { (range: } 40-100) \\
(\mathrm{N}=44 \text { monovision) } \\
81.6 \pm 17.4 \\
\text { (range: } 50-100) \\
(\mathrm{N}=9 \text { emmetropia) }\end{array}$ & $\begin{array}{l}<0.0001 \\
<0.0001 \\
0.11\end{array}$ \\
\hline
\end{tabular}

Notes: Values are presented as mean \pm SD. P-values were calculated by Student's paired $t$-test.

improved from $71.6 \pm 20.3$ to $88.8 \pm 10.0$ and that of near vision from $52.9 \pm 26.6$ to $88.0 \pm 14.1$ in all patients studied. Monovision (44 patients) and emmetropic patients (nine patients) were also analyzed as separate groups with respect to patient satisfaction with far and near vision. In monovision patients, satisfaction with both far and near vision increased significantly $(P<0.0001$, Table 2$)$. In the emmetropia group, the mean patient satisfaction with far and near vision increased from $73.7 \pm 23.7$ to $86.9 \pm 15.3(P=0.22)$ and from $58.9 \pm 29.1$ to $81.6 \pm 17.4(P=0.11)$, respectively, but was not statistically significant, most probably due to the small size of this group. Data for eyes treated either with the FEMTO LDV or with the Visumax femtosecond laser for flap creations were also separately analyzed, but there were no differences between them. Postoperative keratometry readings affected neither dry eye symptoms nor patient satisfaction with far or near vision.

In our monovision group, there was a significant negative correlation between satisfaction with far vision and dry eye symptoms postoperatively ( $r=-0.31,0.04$; Figure $3 \mathrm{~A}$ ). Furthermore, in monovision patients, satisfaction with near vision correlated negatively with postoperative spherical equivalent refraction from target $(r=-0.45, P=0.002$; Figure $3 \mathrm{~B})$. In the emmetropia group, satisfaction with near vision correlated negatively with patient age $(r=-0.69$, $P=0.04$; Figure 3C).

\section{Technical deviations and complications}

With the FEMTO LDV femtosecond laser, the Barraquer eye speculum was used in two eyes. When the excimer laser was used in the FEMTO LDV group, eye tracker came off in one (1\%) eye and was redocked. Opaque bubble layer was observed in two (2\%) eyes treated with FEMTO LDV. Furthermore, there was a tear in one (1\%) corneal flap created with the Visumax femtosecond laser. None of these complications affected the visual acuity of the patients.

\section{Discussion}

Hyperopic correction with LASIK has been considered challenging. ${ }^{16,17}$ In general, patients seeking hyperopic correction are older than those seeking refractive surgery due to myopia or astigmatism. In this study, patient age ranged from 22 to 62 years (mean $49.6 \pm 10.4$ years). Therefore, majority of our patients were treated for presbyopia by using monovision approach.

In recent years, the refractive results of FS-LASIK for hyperopia with and without astigmatism have been reported by many authors ${ }^{9,12,18-30}$ (Table S1). In these studies, predictability, defined as SEQ refraction within $\pm 0.50 \mathrm{D}$ of target SEQ refraction, ranged from $50 \%{ }^{9}$ to $95 \% .{ }^{12}$ Efficacy, defined as an UDVA of 20/20 or better, ranged from $24 \%{ }^{30}$ to $95.7 \% .{ }^{19}$ Safety, as the loss of two or more Snellen lines of CDVA, ranged from $0 \% 12,19,22,24,25,29$ to $6.5 \% .{ }^{21}$ In the present 
A

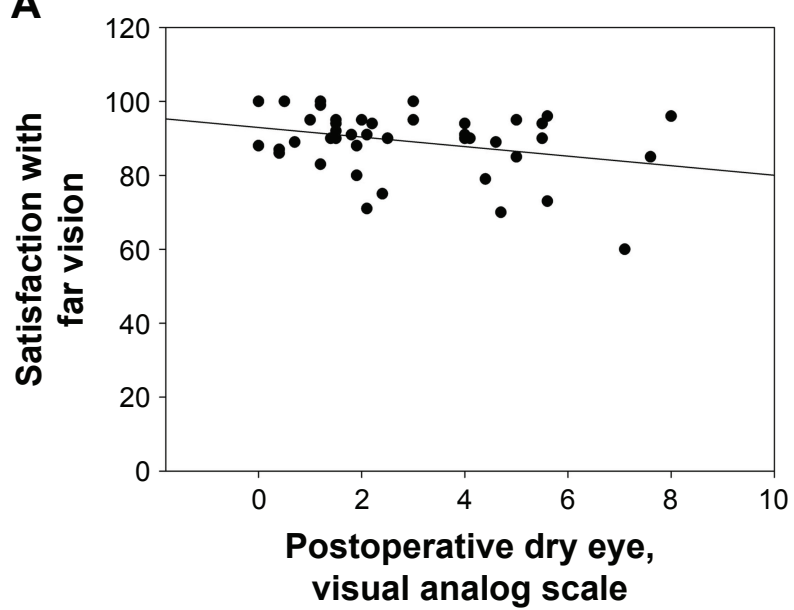

B

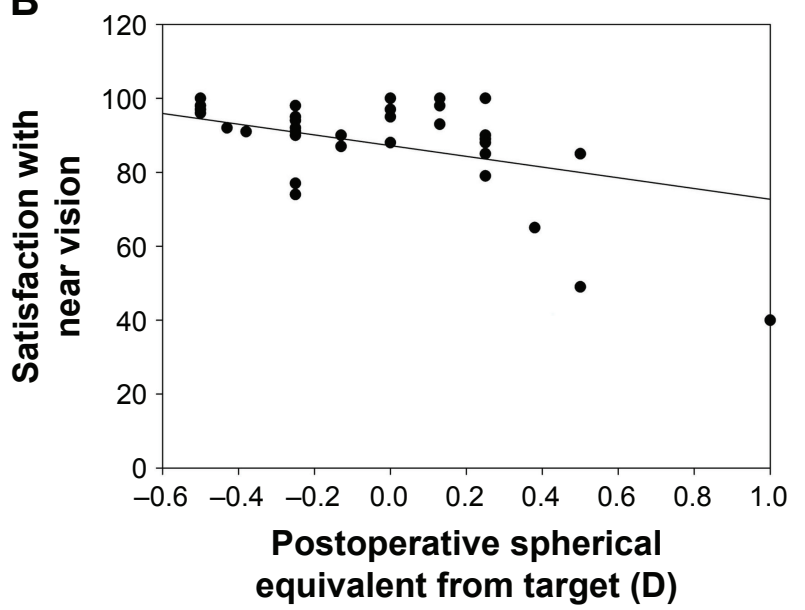

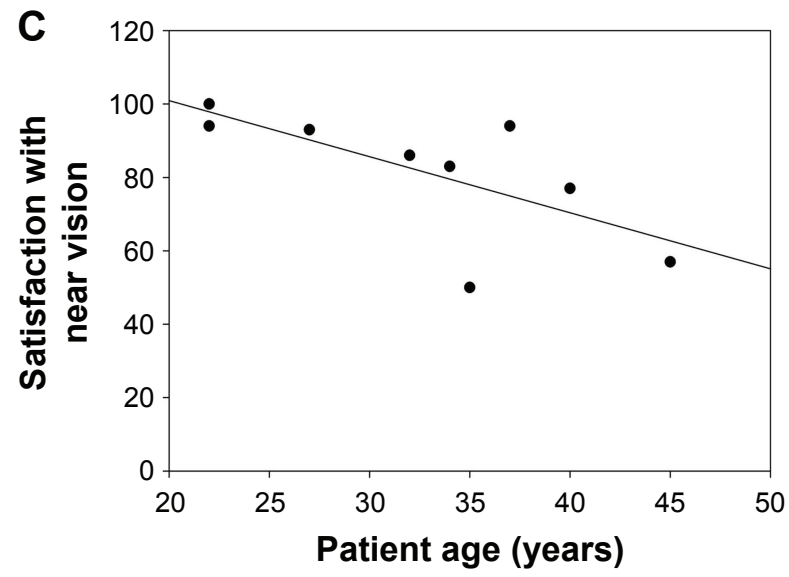

Figure 3 (A) In 44 monovision patients, satisfaction with far vision correlated negatively with postoperative dry eye experience ( $r=-0.3$ I, $P=0.04)$. Patient satisfaction with far vision decreased with increasing dry eye symptoms. (B) In 44 monovision patients, satisfaction with near vision correlated negatively with postoperative spherical equivalent refraction from target $(r=-0.45, P=0.002)$. Patients were more satisfied with their near vision when postoperative spherical equivalent from target was on the myopic side. (C) In nine emmetropic patients, satisfaction with near vision correlated negatively with patient age $(r=-0.69, P=0.04)$. Patient satisfaction with near vision decreased with patient age.

study, $88 \%$ of eyes achieved a predictability within $\pm 0.50 \mathrm{D}$, $91 \%$ of the eyes with the plano target achieved efficacy within $\leq 20 / 20$, and no eyes lost two or more Snellen lines of CDVA.

Most of the studies published on patient satisfaction with LASIK involve all types of refractive corrections, and the studies do not separately report the satisfaction rates for myopia or hyperopia, with or without astigmatism. In a study that analyzed the satisfaction of 13,566 patients with laser vision correction, using either LASIK or laser epithelial keratomileusis, $95 \%$ of patients reported being satisfied with their visual results after surgery and $82.8 \%$ of patients indicated that their vision was better after surgery than it had been with spectacles or contact lenses. ${ }^{31}$ An LASIK review that analyzed the quality of life and patient satisfaction across all sorts of treatments reported an overall patient satisfaction of 95.4\%.${ }^{10}$ On the subjective questionnaire of US naval aviators who had FS-LASIK, 95\% of patients reported that their postoperative vision was better than the preoperative one. ${ }^{12}$ A long-term follow-up (19.9 \pm 24.4 months, between 2000 and 2012) of laser vision correction in physicians by photorefractive keratectomy or LASIK reported an overall satisfaction rate of $95.3 \% .{ }^{15}$ Of the physicians, $84.4 \%$ reported an improvement in the quality of vision compared with the corrected preoperative vision. A study that compared visual satisfaction with LASIK and contact lenses reported that $88 \%$ of former contact lens wearers and $77 \%$ of former glass wearers were strongly satisfied with LASIK at 3 years. ${ }^{14}$

Monovision is a method for presbyopia correction where the dominant eye is typically corrected for distance vision (emmetropia) and the non-dominant eye is corrected for near vision (myopic target). In monovision patients, high levels of patient satisfaction with LASIK utilizing microkeratomes for flap creation have been reported. Goldberg ${ }^{32}$ reported 96\% satisfaction and Miranda and Krueger ${ }^{33}$ reported $92.5 \%$ success rate in myopes and hyperopes groups. 
Later, Goldberg reported a patient satisfaction of 8.22 on a scale from 1 to 10 in monovision hyperopes with a follow-up from 6 to 24 months. ${ }^{34}$ Assil et al $^{35}$ reported a mean overall patient satisfaction of 8.8 (scale 1 to 10 ) for hyperopic presbyopia with 6-month follow-up. In the present study, the postoperative patient satisfaction for far vision in all patients was 88.5 , and for near vision it was 87.9. The corresponding values for monovision patients were 89.2 and 89.3 , respectively. In monovision patients, patient satisfaction for both far and near vision improved significantly within the followup time. In our monovision patients, satisfaction with far vision decreased when dry eye symptoms increased. In this group, as expected, satisfaction with near vision was more evident when postoperative spherical equivalent from target was on the myopic side. In emmetropic patients, satisfaction with their near vision decreased with patient age. According to the results, monovision correction could be favorable for patients even under the age of 40 years.

Albietz et $\mathrm{al}^{36}$ have reported increased dry eye symptoms in hyperopic LASIK patients by using physiological measurements. They speculated that differences in the surface contour following myopic and hyperopic ablations may contribute to increased dry eye symptoms in hyperopic patients. ${ }^{36}$ The most prominent difference between hyperopic and myopic treatments is that in the hyperopic LASIK ablation, the effect is the steepening of the cornea, while in the myopic ablation the effect is a central flattening. The steeper central cornea in hyperopic correction may adversely affect tear film stability and blinking patterns. ${ }^{36}$ Williams et $\mathrm{al}^{37}$ found that patients with steeper pre- and postoperative K-values have more postoperative dry eye symptoms than patients with flatter K-values. In both of those studies, LASIK flaps were made with microkeratome. ${ }^{36,37}$ However, in the present study, postoperative keratometry values did not affect dry eye symptoms. Our patients did not report any significant changes in their self-reported dry eye symptoms during the follow-up. Therefore, the corneal flap seems to be one factor affecting postoperative dry eye symptoms after hyperopic LASIK.

In our previous studies, we compared FS-LASIK and SMILE for myopic treatment. ${ }^{38}$ In the comparison, myopic patients treated with FS-LASIK had no change in self-reported dry eye symptoms, but patients treated with SMILE reported fewer dry eye symptoms after 1-month follow-up than preoperatively. When FS-LASIK-corrected myopic eyes in our previous study and FS-LASIK-corrected hyperopic eyes in the present study were compared, we found no significant changes in postoperative dry eye symptoms. Salomão et $\mathrm{al}^{39}$ compared LASIK-induced dry eye symptoms in myopic eyes after flap creation with mechanical microkeratome and femtosecond laser. The incidence of LASIK-associated dry eye 1-month postoperatively was significantly higher in the microkeratome group (46\%) than in the femtosecond group $(8 \%)$. Flaps made with femtosecond laser are thinner and have less deviation in thickness than flaps made with microkeratome, causing less damage to the afferent sensory nerves in the anterior corneal stroma and may therefore cause less postoperative dryness. ${ }^{39}$ Our study suggests that FS-LASIK for hyperopia does not exacerbate dry eye symptoms even in eyes with steeper corneal curvature.

Our study had some limitations. The data used are based on the normal real-life data of the patients visiting refractive surgery clinics. This fact has its benefits and drawbacks. The results are representative and thus can be easily transferred to a clinical practice. We investigated dry eye experience but did not include any specific analyses of tear film or ocular surface in the study. Our follow-up time was 1 month, which did not allow further analyses over a longer period of time. On the other hand, the dry eye symptoms after LASIK are multifactorial and are known to be most evident during the first month after operation and diminish after that. ${ }^{40}$ Although VAS are easy-to-use and practical methods and thus very suitable for the real-life type of studies, they have certain limitations. Patients often avoid marking in the ends of the VAS scale and thus the linearity of the satisfaction and symptom scale at the ends of VAS might be criticized. Refractive corrections for hyperopia are much more uncommon that myopic corrections yielding relative low number of cases in these types of studies.

\section{Conclusion}

In conclusion, most of the patients in the present study were having monovision correction for presbyopia. We investigated dry eye symptoms and patient satisfaction for near and far vision preoperatively and 1 month after the operation using the self-reported VAS. There were no significant changes in dry eye symptoms during the 1-month follow-up. In monovision patients, satisfaction with both far and near vision improved significantly during the follow-up. Also in them, patient satisfaction with far vision decreased when dry eye symptoms increased. As predicted, monovision patients were more satisfied with their near vision when postoperative spherical equivalent from target was on the myopic side. Satisfaction with near vision in emmetropic patients decreased with increasing age. 


\section{Acknowledgment}

Optician Vesa Alho is gratefully acknowledged for his skillful technical assistance.

\section{Disclosure}

Dr. Pietilä has financial interest in the Ziemer Ophthalmic Systems and the other authors have no conflicts of interest in this work.

\section{References}

1. Nettune GR, Pflugfelder SC. Post-LASIK tear dysfunction and dysesthesia. Ocul Surf. 2010;8(3):135-145.

2. Yu EYW, Leung A, Rao S, Lam DSC. Effect of laser in situ keratomileusis on tear stability. Ophthalmology. 2000;107(12):2131-2135.

3. Stern ME, Beuerman RW, Fox RI, Gao J, Mircheff AK, Pflugfelder SC. The pathology of dry eye: the interaction between the ocular surface and lacrimal glands. Cornea. 1998;17(6):584-589.

4. Pietila J, Makinen P, Pajari S, Uusitalo H. Excimer laser photorefractive keratectomy for hyperopia. J Refract Surg. 1997;13(6):504-510.

5. Pershin KB, Pashinova NF. Refractive surgery for hyperopia. J Refract Surg. 2000;16(2 Suppl):S242-S246. doi:10.3928/1081-597X20000302-09

6. O'Brart DP, Patsoura E, Jaycock P, Rajan M, Marshall J. Excimer laser photorefractive keratectomy for hyperopia: 7.5-year follow-up. J Cataract Refract Surg. 2005;31(6):1104-1113. doi:10.1016/j.jcrs.2004. 10.051

7. Jaycock PD, O'Brart DP, Rajan MS, Marshall J. 5-year follow-up of LASIK for hyperopia. Ophthalmology. 2005;112(2):191-199. doi:10. 1016/j.ophtha.2004.09.017

8. Dave R, O'Brart DP, Wagh VK, et al. Sixteen-year follow-up of hyperopic laser in situ keratomileusis. J Cataract Refract Surg. 2016;42(5): 717-724. doi:10.1016/j.jcrs.2016.03.028

9. Reinstein DZ, Carp GI, Archer TJ, et al. LASIK for the correction of high hyperopic astigmatism with epithelial thickness monitoring. J Refract Surg. 2017;33(5):314-321. doi:10.3928/1081597X-20170111-04

10. Solomon KD, Fernandez de Castro LE, Sandoval HP, et al. LASIK world literature review: quality of life and patient satisfaction. Ophthalmology. 2009;116(4):691-701. doi:10.1016/j.ophtha.2008.12.037

11. Saragoussi JJ, Djadi-Prat J, Lebuisson D-A, Arson B, Saragoussi D Qualité de vie après LASIK : partie II. Qualité de vie et satisfaction d'une population de patients opérée par LASIK [Quality of life after LASIK: part II. Quality of life and satisfaction of a population of patients treated with LASIK]. J Fr Ophtalmol. 2011;34(5):294-302. doi:10.1016/j.jfo.2011.01.007

12. Tanzer DJ, Brunstetter T, Zeber R, et al. Laser in situ keratomileusis in United States Naval aviators. J Cataract Refract Surg. 2013;39(7): 1047-1058. doi:10.1016/j.jcrs.2013.01.046

13. Eydelman M, Hilmantel G, Tarver ME, et al. Symptoms and satisfaction of patients in the Patient-Reported Outcomes With Laser in situ keratomileusis (PROWL) studies. JAMA Ophthalmol. 2017;135(1):13-22. doi:10.1001/jamaophthalmol.2016.4587

14. Price MO, Price DA, Bucci FA Jr, Durrie DS, Bond WI, Price FW Jr. Three-year longitudinal survey comparing visual satisfaction with LASIK and contact lenses. Ophthalmology. 2016;123(8):1659-1666. doi:10.1016/j.ophtha.2016.04.003

15. Pasquali TA, Smadja D, Savetsky MJ, Reggiani Mello GH, Alkhawaldeh F, Krueger RR. Long-term follow-up after laser vision correction in physicians: quality of life and patient satisfaction. J Cataract Refract Surg. 2014;40(3):395-402. doi:10.1016/j.jcrs.2013.08.052

16. Sher NA. Hyperopic refractive surgery. Curr Opin Ophthalmol. 2001; 12(4):304-308.

17. O'Brart DP. The status of hyperopic laser-assisted in situ keratomileusis. Curr Opin Ophthalmol. 1999;10(4):247-252.
18. Garcia-Gonzalez M, Iglesias-Iglesias M, Rodriguez-Casanova PD, Gros-Otero J, Teus MA. Femtosecond laser-assisted LASIK with and without the adjuvant use of mitomycin $\mathrm{C}$ to correct hyperopia. J Refract Surg. 2018;34(1):23-28. doi:10.3928/1081597X-20171116-01

19. El-Naggar MT, Hovaghimian DG. Assessment of refractive outcome of femtosecond-assisted LASIK for hyperopia correction. Electron Physician. 2017;9(3):3958-3965. doi:10.19082/3958

20. Schallhorn SC, Teenan D, Venter JA, et al. Monovision LASIK versus presbyopia-correcting IOLs: comparison of clinical and patient-reported outcomes. J Refract Surg. 2017;33(11):749-758. doi:10.3928/10815 97X-20170721-03

21. Plaza-Puche AB, El Aswad A, Arba-Mosquera S, Wrobel-Dudzinska D, Abdou AA, Alio JL. Optical profile following high hyperopia correction with a 500-Hz excimer laser system. J Refract Surg. 2016;32(1):6-13. doi:10.3928/1081597X-20151207-06

22. Courtin R, Saad A, Grise-Dulac A, Guilbert E, Gatinel D. Changes to corneal aberrations and vision after monovision in patients with hyperopia after using a customized aspheric ablation profile to increase corneal asphericity (Q-factor). J Refract Surg. 2016;32(11):734-741. doi:10.3928/1081597X-20160810-01

23. Plaza-Puche AB, Yebana P, Arba-Mosquera S, Alio JL. Three-year follow-up of hyperopic LASIK using a 500-Hz excimer laser system. $J$ Refract Surg. 2015;31(10):674-682. doi:10.3928/1081597X20150928-06

24. Antonios R, Arba Mosquera S, Awwad ST. Hyperopic laser in situ keratomileusis: comparison of femtosecond laser and mechanical microkeratome flap creation. J Cataract Refract Surg. 2015;41(8):1602-1609. doi:10.1016/j.jcrs.2014.11.049

25. Alio JL, El Aswad A, Vega-Estrada A, Javaloy J. Laser in situ keratomileusis for high hyperopia ( $>5.0$ diopters) using optimized aspheric profiles: efficacy and safety. J Cataract Refract Surg. 2013;39(4):519-527. doi:10.1016/j.jcrs.2012.10.045

26. Leccisotti A. Femtosecond laser-assisted hyperopic laser in situ keratomileusis with tissue-saving ablation: analysis of 800 eyes. $J$ Cataract Refract Surg. 2014;40(7):1122-1130. doi:10.1016/j.jcrs.2013. 11.031

27. Ivarsen A, Naeser K, Hjortdal J. Laser in situ keratomileusis for high astigmatism in myopic and hyperopic eyes. J Cataract Refract Surg. 2013;39(1):74-80. doi:10.1016/j.jcrs.2012.08.054

28. Kanellopoulos AJ. Topography-guided hyperopic and hyperopic astigmatism femtosecond laser-assisted LASIK: long-term experience with the $400 \mathrm{~Hz}$ eye-Q excimer platform. Clin Ophthalmol. 2012;6:895-901. doi:10.2147/OPTH.S23573

29. Gil-Cazorla R, Teus MA, de Benito-Llopis L, Mikropoulos DG. Femtosecond laser vs mechanical microkeratome for hyperopic laser in situ keratomileusis. Am J Ophthalmol. 2011;152(1):16-21. doi:10.1016/ j.ajo.2011.01.009

30. Ghanem RC, de la Cruz J, Tobaigy FM, Ang LP, Azar DT. LASIK in the presbyopic age group: safety, efficacy, and predictability in 40- to 69-year-old patients. Ophthalmology. 2007;114(7):1303-1310. doi:10. 1016/j.ophtha.2006.10.026

31. Brown MC, Schallhorn SC, Hettinger KA, Malady SE. Satisfaction of 13,655 patients with laser vision correction at 1 month after surgery. $J$ Refract Surg. 2009;25(7 Suppl):S642-S646.

32. Goldberg DB. Laser in situ keratomileusis monovision. J Cataract Refract Surg. 2001;27(9):1449-1455.

33. Miranda D, Krueger RR. Monovision laser in situ keratomileusis for pre-presbyopic and presbyopic patients. J Refract Surg. 2004;20(4): 325-328.

34. Goldberg DB. Comparison of myopes and hyperopes after laser in situ keratomileusis monovision. J Cataract Refract Surg. 2003;29(9): 1695-1701

35. Assil KK, Chang SH, Bhandarkar SG, Sturm JM, Christian WK. Photopic pupillometry-guided laser in situ keratomileusis for hyperopic presbyopia. J Cataract Refract Surg. 2008;34(2):205-210. doi:10. 1016/j.jcrs.2007.09.021 
36. Albietz JM, Lenton LM, McLennan SG. Effect of laser in situ keratomileusis for hyperopia on tear film and ocular surface. $J$ Refract Surg. 2002;18(2):113-123.

37. Williams LB, Dave SB, Moshirfar M. Correlation of visual outcome and patient satisfaction with preoperative keratometry after hyperopic laser in situ keratomileusis. J Cataract Refract Surg. 2008;34(7):1083-1088. doi:10.1016/j.jcrs.2008.03.018

38. Pietilä J, Huhtala A, Mäkinen P, et al. Uncorrected visual acuity, postoperative astigmatism, and dry eye symptoms are major determinants of patient satisfaction: A comparative, real-life study of femtosecond laser in situ keratomileusis and small incision lenticule extraction for myopia. Clin Ophthalmol. 2018;12:1741-1755. doi:10.2147/OPTH. S172894
39. Salomão MQ, Ambrósio R Jr, Wilson SE. Dry eye associated with laser in situ keratomileusis: mechanical microkeratome versus femtosecond laser. J Cataract Refract Surg. 2009;35(10):1756-1760. doi:10.1016/j. jcrs.2009.05.032

40. Toda I. Dry eye after LASIK. Invest Ophthalmol Vis Sci. 2018;59: DES109-DES115. doi:10.1167/iovs.17-23678 


\section{Supplementary materials}

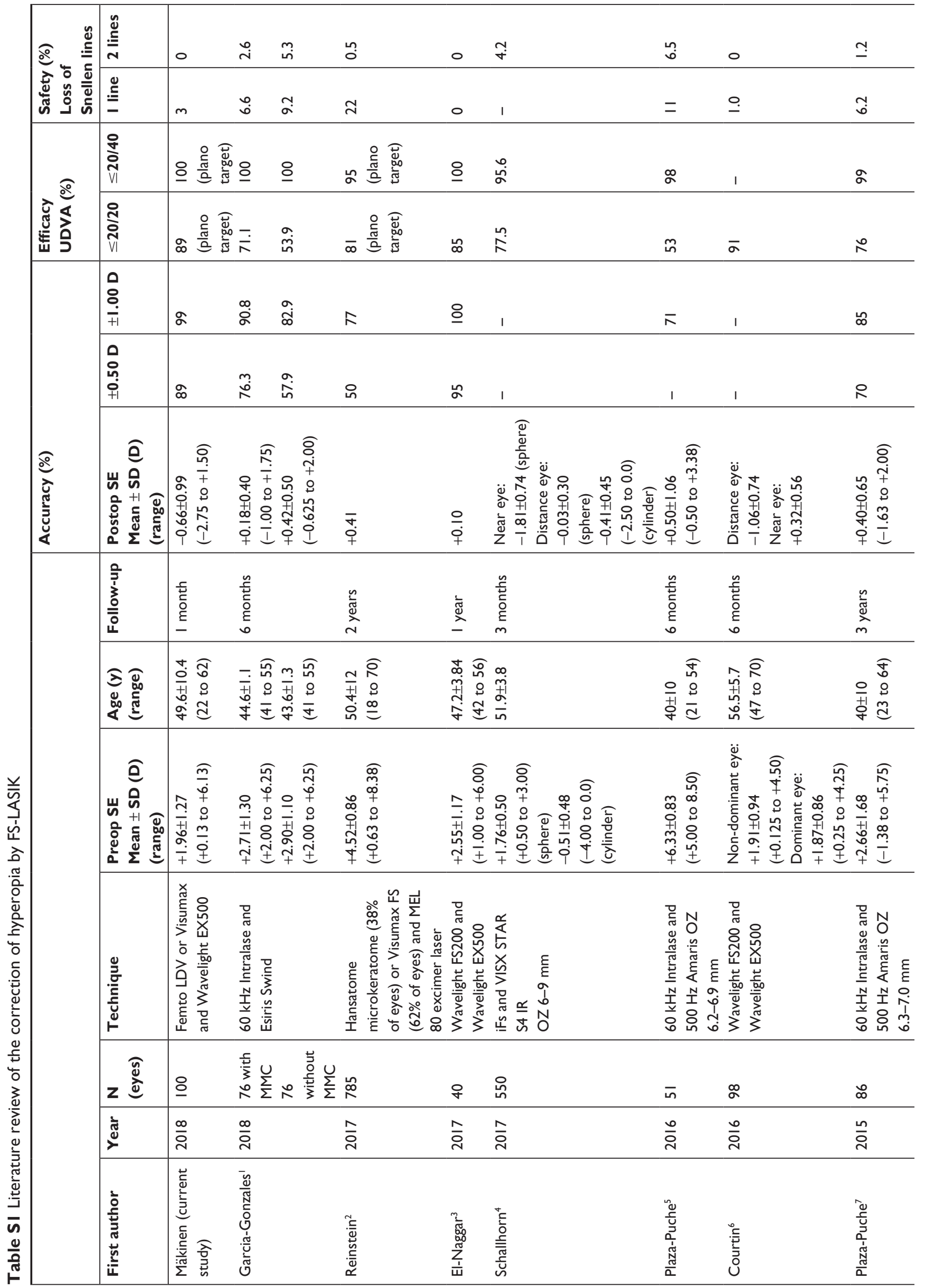




\begin{tabular}{|c|c|c|c|c|c|c|c|}
\hline 0 & 0 & 0 & $\stackrel{t}{0}$ & 1 & $\stackrel{+}{\mathrm{i}}$ & 0 & $0-+$ \\
\hline 0 & $\infty$ & $\theta$ & $\stackrel{m}{n}$ & 1 & $\dot{\tilde{i}}$ & 0 & $\tilde{m} \simeq \hat{N}$ \\
\hline
\end{tabular}

으 응 ㅇำ

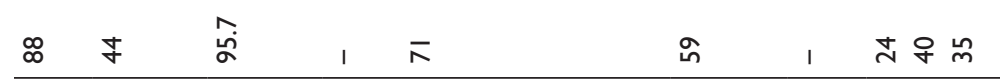

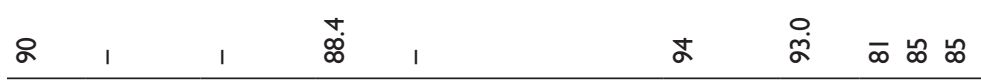

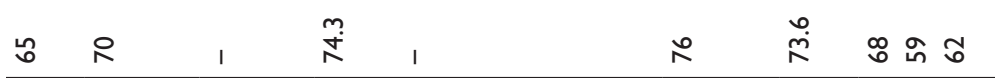

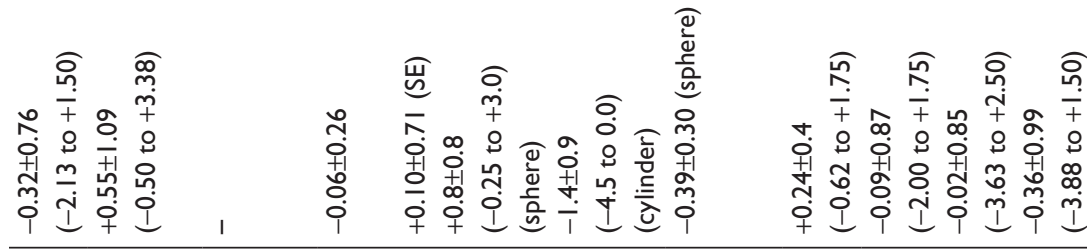

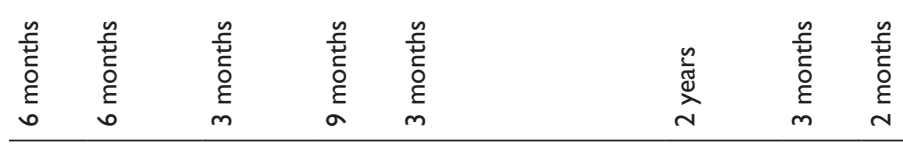

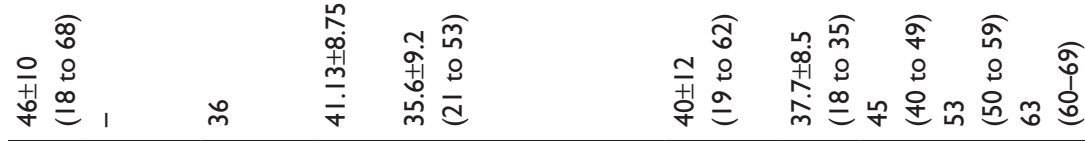

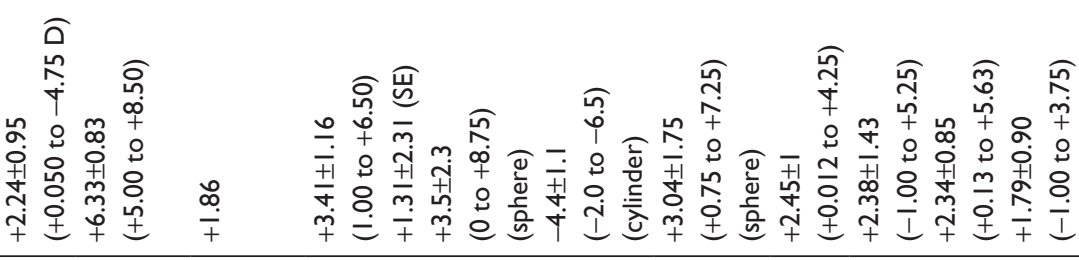

\begin{tabular}{|c|c|c|c|c|}
\hline 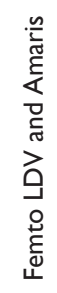 & 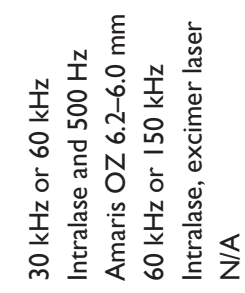 & 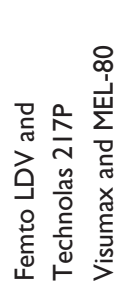 & 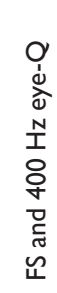 & 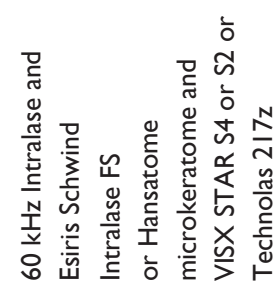 \\
\hline
\end{tabular}

\begin{tabular}{|c|c|c|c|c|c|c|c|}
\hline 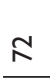 & $\hat{\sim}$ & $\stackrel{\sim}{\sim}$ & ০ి & กี & రి & $\mathbb{N}$ & f) \\
\hline$\frac{\text { 늠 }}{\bar{N}}$ & $\frac{m}{i}$ & $\bar{m}$ & $\stackrel{\nabla}{\circ}$ & $\frac{m}{i}$ & $\bar{i}$ & $\overline{\bar{i}}$ & ڤ્ণ \\
\hline 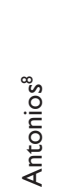 & 은 & 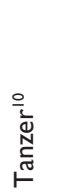 & $\begin{array}{l}\overline{\bar{u}} \\
\overline{\mathscr{u}} \\
\underline{G}\end{array}$ & $\begin{array}{l}\bar{N} \\
\bar{v} \\
\bar{w} \\
\underline{\underline{N}} \\
\underline{z}\end{array}$ & 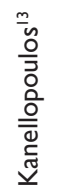 & 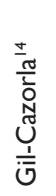 & 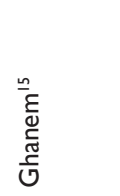 \\
\hline
\end{tabular}




\section{References}

1. Garcia-Gonzalez M, Iglesias-Iglesias M, Rodriguez-Casanova PD, Gros-Otero J, Teus MA. Femtosecond laser-assisted LASIK with and without the adjuvant use of mitomycin $\mathrm{C}$ to correct hyperopia. J Refract Surg. 2018;34(1):23-28. doi:10.3928/1081597X-20171116-01

2. Reinstein DZ, Carp GI, Archer TJ, et al. LASIK for the correction of high hyperopic astigmatism with epithelial thickness monitoring. $J$ Refract Surg. 2017;33(5):314-321. doi:10.3928/1081597X-20170111-04

3. El-Naggar MT, Hovaghimian DG. Assessment of refractive outcome of femtosecond-assisted LASIK for hyperopia correction. Electron Physician. 2017;9(3):3958-3965. doi:10.19082/3958

4. Schallhorn SC, Teenan D, Venter JA, et al. Monovision LASIK versus presbyopia-correcting IOLs: comparison of clinical and patient-reported outcomes. J Refract Surg. 2017;33(11):749-758. doi:10.3928/10815 97X-20170721-03

5. Plaza-Puche AB, El Aswad A, Arba-Mosquera S, Wrobel-Dudzinska D, Abdou AA, Alio JL. Optical profile following high hyperopia correction with a 500-Hz excimer laser system. J Refract Surg. 2016;32(1):6-13. doi:10.3928/1081597X-20151207-06

6. Courtin R, Saad A, Grise-Dulac A, Guilbert E, Gatinel D. Changes to corneal aberrations and vision after monovision in patients with hyperopia after using a customized aspheric ablation profile to increase corneal asphericity (Q-factor). JRefract Surg. 2016;32(11):734-741. doi:10.3928/ 1081597X-20160810-01

7. Plaza-Puche AB, Yebana P, Arba-Mosquera S, Alio JL. Three-year follow-up of hyperopic LASIK using a 500-Hz excimer laser system. $J$ Refract Surg. 2015;31(10):674-682. doi:10.3928/1081597X20150928-06
8. Antonios R, Arba Mosquera S, Awwad ST. Hyperopic laser in situ keratomileusis: comparison of femtosecond laser and mechanical microkeratome flap creation. J Cataract Refract Surg. 2015;41(8):1602-1609. doi:10.1016/j.jcrs.2014.11.049

9. Alio JL, El Aswad A, Vega-Estrada A, Javaloy J. Laser in situ keratomileusis for high hyperopia ( $>5.0$ diopters) using optimized aspheric profiles: efficacy and safety. J Cataract Refract Surg. 2013;39(4):519-527. doi:10.1016/j.jcrs.2012.10.045

10. Tanzer DJ, Brunstetter T, Zeber R, et al. Laser in situ keratomileusis in United States Naval aviators. J Cataract Refract Surg. 2013;39(7): 1047-1058. doi:10.1016/j.jcrs.2013.01.046

11. Leccisotti A. Femtosecond laser-assisted hyperopic laser in situ keratomileusis with tissue-saving ablation: analysis of 800 eyes. J Cataract Refract Surg. 2014;40(7):1122-1130. doi:10.1016/j.jcrs.2013.11.031

12. Ivarsen A, Naeser K, Hjortdal J. Laser in situ keratomileusis for high astigmatism in myopic and hyperopic eyes. J Cataract Refract Surg. 2013;39(1):74-80. doi:10.1016/j.jcrs.2012.08.054

13. Kanellopoulos AJ. Topography-guided hyperopic and hyperopic astigmatism femtosecond laser-assisted LASIK: long-term experience with the $400 \mathrm{~Hz}$ eye-Q excimer platform. Clin Ophthalmol. 2012;6:895-901. doi:10.2147/OPTH.S23573

14. Gil-Cazorla R, Teus MA, de Benito-Llopis L, Mikropoulos DG. Femtosecond laser vs mechanical microkeratome for hyperopic laser in situ keratomileusis. Am J Ophthalmol. 2011;152(1):16-21. doi:10. 1016/j.ajo.2011.01.009

15. Ghanem RC, de la Cruz J, Tobaigy FM, Ang LP, Azar DT. LASIK in the presbyopic age group: safety, efficacy, and predictability in 40- to 69-year-old patients. Ophthalmology. 2007;114(7):1303-1310. doi:10. 1016/j.ophtha.2006.10.026

\section{Clinical Ophthalmology}

\section{Publish your work in this journal}

Clinical Ophthalmology is an international, peer-reviewed journal covering all subspecialties within ophthalmology. Key topics include: Optometry; Visual science; Pharmacology and drug therapy in eye diseases; Basic Sciences; Primary and Secondary eye care; Patient Safety and Quality of Care Improvements. This journal is indexed on Submit your manuscript here: http://www.dovepress.com/clinical-ophthalmology-journal

\section{Dovepress}

PubMed Central and CAS, and is the official journal of The Society of Clinical Ophthalmology (SCO). The manuscript management system is completely online and includes a very quick and fair peer-review system, which is all easy to use. Visit http://www.dovepress.com/ testimonials.php to read real quotes from published authors. 